\title{
Epidemiology of traumatic spinal injuries in Brazil: systematic review
}

\author{
Ricardo Vieira Botelho', Luciana Dini Gianini Albuquerque', \\ Rafael Bastianello Junior ${ }^{2}$, Aluízio Augusto Arantes Júnior ${ }^{3}$
}

\begin{abstract}
Prevention remains the most effective way to reduce the burden of spinal injuries (SI). Estimating the incidence and causes of SI is essential for the development of prevention programs. To reveal the current state of Brazilian ST epidemiology. To evaluate the current state of Brazilian SI epidemiology, we performed an electronic search using the Lilacs database (Latin American and Caribbean Health Sciences Literature). Fifteen papers and one unsubmitted ongoing study (BH project) reported the epidemiologic status of ST in Brazil. The mean age of SI patients was 34,75 years, and $84 \%$ of patients were male. The most commonly affected segment was the cervical spine (36.65\%). The incidence ranged from 16 to 26 patients per million per year (average 21 per million per year). The average rate of complete spinal cord injury among five papers was $34 \%$. The average mortality in four papers was $11.58 \%$. Analyzing published national epidemiological data enables the estimation of the current state of Brazilian Sl epidemiology.
\end{abstract}

\section{KEYWORDS}

Epidemiology, spinal cord injuries, spinal fractures.

\section{RESUMO}

Epidemiologia do trauma raquimedular no Brasil: revisão sistemática

A prevenção continua a ser a forma mais eficaz de reduzir o ônus das lesões na coluna vertebral (TRM). A estimativa da incidência e das causas do TRM é essencial para o desenvolvimento de programas de prevenção. Para revelar os dados epidemiológicos do TRM no Brasil, foi realizada uma busca eletrônica utilizando o banco de dados Lilacs (Literatura do Caribe em Ciências da Saúde da América Latina e Caribe). Quinze artigos publicados em um estudo em andamento (projeto $\mathrm{BH}$ ) relataram a situação epidemiológica do TRM no Brasil. A idade média dos pacientes foi de 34,75 anos; $84 \%$ dos pacientes eram do sexo masculino. O segmento vertebral mais afetado foi a coluna cervical (36,65\%). A incidência variou de 16 a 26 pacientes por milhão por ano (média de 21 por milhão por ano). A média de lesão medular completa entre cinco trabalhos que descreveram a variável foi de $34 \%$. A média de mortalidade em quatro trabalhos foi de $11,58 \%$. A análise dos trabalhos permite estimar os dados epidemiológicos nacionais, revelando sua distribuição e gravidade, possibilitando comparações com estudos futuros.

\section{PALAVRAS-CHAVE}

Epidemiologia, traumatismos da medula espinal, fraturas de coluna vertebral.

1 Professor, permanent advisor, Post-Graduation Program in Health Sciences - Instituto de Assistência Médica ao Servidor Público Estadual (Iamspe), São Paulo, SP, Brazil.

2 Fellow, Programa Institucional de Bolsas de Iniciação Científica/Conselho Nacional de Desenvolvimento Científico e Tecnológico (Pibic/ CNPq), Post-Graduation Program in Health Sciences - Iamspe, São, Paulo, SP, Brazil.

3 Professor, Medicine School, Minas Gerais Federal University (UFMG), Belo Horizonte, MG, Brazil. 


\section{Introduction}

Traumatic spinal and spinal cord injuries (SI) are important causes of morbidity and mortality and a major cause of loss of independence and self-esteem in young adults. ${ }^{1}$ Prevention remains the most effective way to reduce the SI burden. The causes of trauma depend on the types of housing present in large urban centers as well as the population's habits and education level. ${ }^{1}$ Estimating the incidence and causes of SI is essential for the development of prevention programs. ${ }^{2}$ No recent studies have detailed SI epidemiology across Brazil. However, it is possible to pool the data from several published reports from different cities to estimate the country's epidemiological status. ${ }^{1-15}$ The objective of this study was to reveal the current state of Brazilian SI epidemiology.

\section{Methods}

To evaluate Brazilian SI epidemiology, we performed an electronic search using the Lilacs database (Latin American and Caribbean Health Sciences Literature), between January 1964 to October 2012. The search strategy involving $\mathrm{MeSH}$ terms and Portuguese keywords was as follows: "Traumatismos da medula espinal" ("spinal cord injuries") AND "estudos de incidência" ("incidence studies") OR "estudos de prevalência" ("prevalence studies") OR "epidemiologia" ("epidemiology") OR "epidemiologia da fratura da coluna espinal" ("spine fracture epidemiology") OR "trauma da coluna" ("spinal trauma").

Data from ongoing unpublished epidemiological studies were included with the permission of the authors. Studies that described series of cases from isolated institutions that were not of a strictly epidemiological nature were excluded.

\section{Results}

Fifteen papers and one unsubmitted ongoing study in the city of Belo Horizonte (BH project) yielded data on the epidemiologic status of SI in Brazil. The majority of the papers were based on regional hospital registry data. One paper was based on the responses to a questionnaire administered to all hospitals in the National Public Health system. ${ }^{2}$ Another was a crosssectional study detailing the prevalence of hospitalized SCI patients. ${ }^{3}$ One paper specifically described the epidemiology related to diving in shallow water in the city of Ribeirão Preto. ${ }^{4}$ Another study described the epidemiology of SI by fire arm projectiles (FAP) in a hospital in Curitiba. ${ }^{5}$ Data from these works, due to their specificity, were not pooled together with the other papers.

\section{Studied regions}

Geographically and economically, Brazil is divided into five regions: southeast, south, middle west, north and northeast. We identified at least one SI study from each region (Figure 1).

Southeast region: six studies reported SI epidemiology data from the southeast region, five in the state of São Paulo, ${ }^{1,6-9}$ and one (BH project) in the state of Minas Gerais, in the capital, Belo Horizonte. ${ }^{*}$

Middle west region: one study described SI epidemiology in the state of Goiás, city of Goiânia. ${ }^{10}$

North region: Two papers were published about the same city (Belém) in the state of Pará. ${ }^{11}$ Another study was performed in São Luís, in the state of Maranhão.

Northeast region: three papers were performed in the northeastern states of Piauí, ${ }^{12}$ Pernambuco ${ }^{13}$ and Sergipe. ${ }^{14}$

Nationally based papers: two papers were based on national information. One was based on patients with spinal cord injuries who were treated in the hospitals belonging to the National Public Health System (SUS), ${ }^{2}$ whereas the other was based on SI rehabilitation hospitals throughout the country. ${ }^{3}$

\section{Gender and age}

Data from five studies and the $\mathrm{BH}$ project ${ }^{1-3,10,13}$ revealed a mean age of 34,75 years for SI patients. Eighty-four percent of patients were male.

\section{Incidence of spinal injuries}

In three hospital-based studies and the $\mathrm{BH}$ project, the population of the city was provided, permitting estimates of SI incidence. ${ }^{1,6,12}$ In Piauí, the incidence was 16 SI cases per million inhabitants per year. In the region of Francisco Morato, the incidence was approximately 20 cases per million inhabitants, and in the northern city of São Paulo, the incidence of serious cervical SI was approximately 11 per million per year. Because cervical traumas comprised half of all injuries discussed in that study, the estimated incidence was 22 per million per year. The $\mathrm{BH}$ project counted 224 injured patients

* Data from this study were kindly supplied by Dr. Aluizio Arantes (personal communication). 
over eight months. Eighteen percent (18.3\%) of these patients were from Belo Horizonte. The city's estimated population in 2010 was $2,238,526$ citizens, making the annual incidence 26 per million per year (25.57).

In these studies, the incidence ranged from 16 to 26 patients per million per year, with an average of 21 per million per year. The national studies ${ }^{2,3}$ were considered cross-sectional studies of admitted patients with spinal cord injuries.

\section{Causes}

In nine studies (Recife, Goiânia, Belém, northern São Paulo, Francisco Morato, southern São Paulo, of São Paulo, Santo André, São Luís and Teresina), the most frequent cause of injury was a fall from a height, mainly from rooftops (Table 1). This is a unique consequence of the habitation types in the suburbs of large Brazilian urban centers. The rooftop is often compatible with leisure activities. As a result, falls from rooftops are relatively frequent. For this reason, rooftop falls have become a national public health problem. The rates and distributions of SI causes are described in table 1 and figure 1.

In Belo Horizonte and Aracaju, the main cause of SI was car accidents ( $39.8 \%$ and $40.8 \%$, respectively). In one of the national studies, ${ }^{3}$ the main cause was motor vehicle accidents (41.7\%).

Injuries by firearm projectile (FAP) caused $4.76 \%$ of traumas in Recife, $13 \%$ in Goiás, $36.7 \%$ in the central city of São Paulo (4) (1990), 8.1\% in Heliópolis (south part of São Paulo), $18 \%$ in Santo André, $11.9 \%$ in Teresina and $27.5 \%$ in Sergipe. In Belém (2002), 13\% of traumas were described as caused by violence at work. In the national study by da Paz et al., ${ }^{3} 26.9 \%$ were caused by FAP.

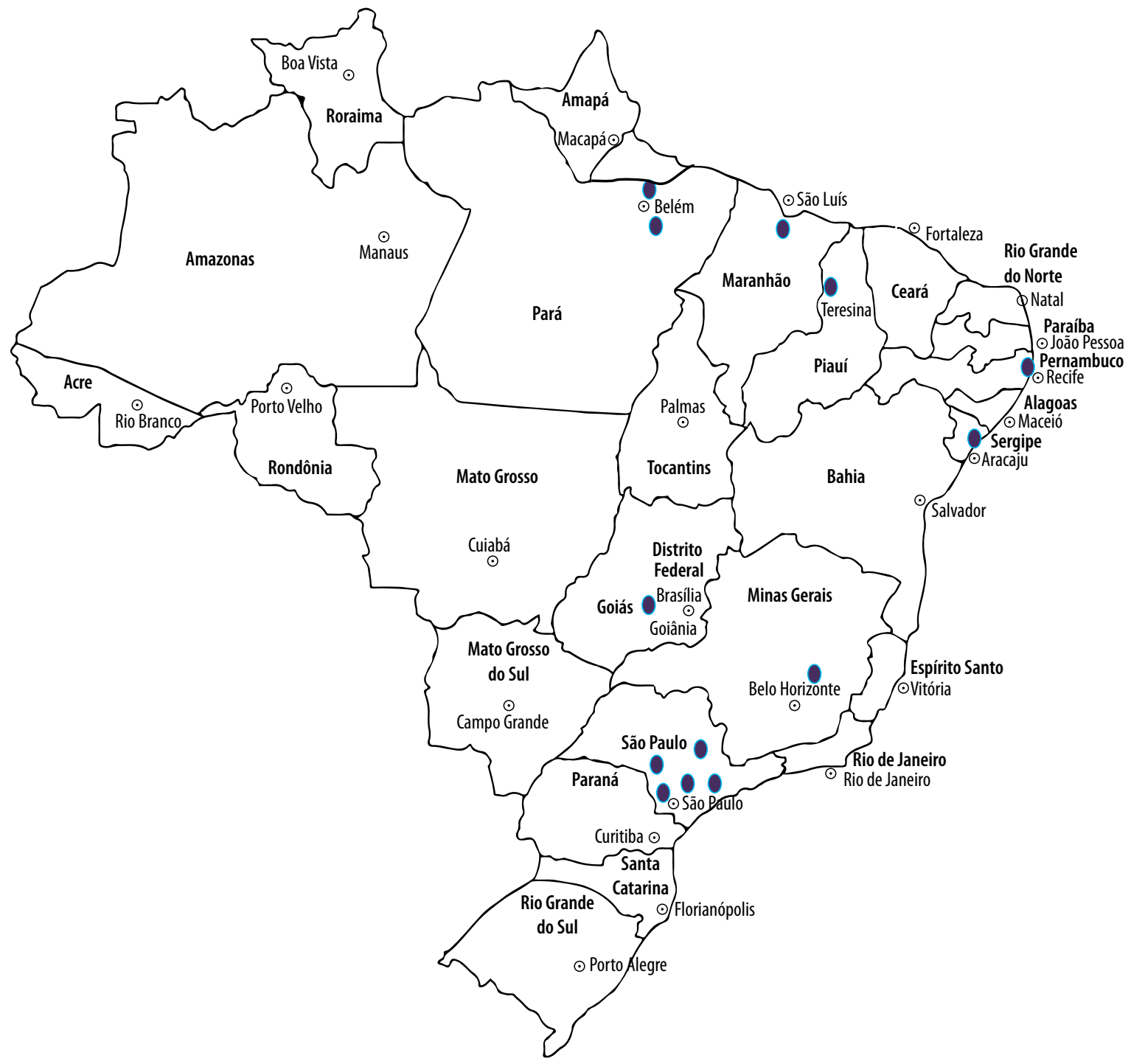

Figure 1 - Regional distribution of Spinal trauma among Brazilian states/cities. 


\begin{tabular}{|c|c|c|c|c|c|c|}
\hline State/City & Falls & Auto & Motorcycle & Gunshot & Diving & Other \\
\hline Pernambuco/Recife & 1.91 & 4.76 & 19.05 & 4.76 & - & 9.5 \\
\hline Goiás/Goiânia & 31 & 44 & 17 & 13 & 9 & 8 \\
\hline São Paulo/São Paulo (Downtown) & 14.8 & & & 26.9 & 9.3 & - \\
\hline Pará/Belém (2002) & 41.2 & 23.1 & & 23.7 & 5 & 13 \\
\hline Pará/Belém (2003) & 39.6 & 8.4 & & 24.4 & 7.12 & 3.6 \\
\hline São Paulo/Francisco Morato & 45.1 & 18.7 & & & & \\
\hline São Paulo/São Paulo (South) & 63 & 10 & 14 & 18 & - & - \\
\hline Piauí/Teresina & 39.6 & 24.4 & & 24.4 & 7.12 & 3.6 \\
\hline São Paulo/Santo André & 47 & 14 & 10 & 18 & - & - \\
\hline São Paulo/São Paulo (North) & 39 & 20 & 4 & 2.3 & 10 & 24.7 \\
\hline Sergipe/Aracaju & 44 & 18.5 & 11.2 & 16.3 & 24.5 & 15.2 \\
\hline Minas Gerais/Belo Horizonte & 34.8 & 39.8 & - & 9.5 & 2.9 & $6.6^{*}$ \\
\hline Maranhão/São Luís & 42.6 & 24.2 & 17.2 & 12.6 & 3.4 & \\
\hline
\end{tabular}

* Unpublished epidemiological study.

\section{Affected spine segments}

The most commonly affected spinal segment was the cervical spine (Table 2). In ten studies, injuries in the cervical spine occurred at a mean rate of $36.65 \%$ (ranging from 26.4 to $62.9 \%$ ) (Table 2).

\begin{tabular}{lc}
\hline Table 2 - Percentage of cervical spine lesions by city \\
\hline City & $\begin{array}{c}\text { \% patients with } \\
\text { lesions in the } \\
\text { cervical spine }\end{array}$ \\
\hline Aracaju & 48.3 \\
Belo Horizonte & $62.9^{*}$ \\
Teresina & 51 \\
Santo André (spinal cord injuries) & 50 \\
Belém (2003) & 30.4 \\
Belém (2002) & 36.25 \\
Goiânia & 45 \\
Francisco Morato & $36.1^{*}$ \\
São Paulo (South) & 39.5 \\
São Luís & 26.4 \\
\hline
\end{tabular}

* Pooled cervical and cervico-thoracic injuries.

\section{Complete SI rates}

The percentage of patients with complete neurological lesions (tetraplegia or paraplegia, with complete sensitivity deficits) are presented for each city (Table 3). The studies carried out in Recife, Goiânia, Francisco Morato, Teresina and Belo Horizonte described the percentage of patients with complete spinal cord injuries. Data based on spinal cord injury papers were excluded, as were data from
Recife $^{13}$ (this paper analyzed only thoracic and lumbar lesions, with $2.3 \%$ being complete lesions) and data from the north zone of the city of São Paulo ${ }^{1}$ (this paper analyzed only cervical lesions). The average rate of complete spinal cord injury in the remaining five papers was $34 \%$.

\begin{tabular}{lc}
\hline \multicolumn{2}{c}{ Table 3 - Percentage of complete spinal cord injuries } \\
\hline City & \% ASIA A \\
\hline Goiânia & 43 \\
Belém (2002) & 26 \\
Francisco Morato & 26.1 \\
Teresina & 50 \\
Belo Horizonte & 23 \\
Mean & 34 \\
\hline
\end{tabular}

\section{Mortality rates}

Three papers and the $\mathrm{BH}$ project reported their in-hospital mortality rates. Barros et al., ${ }^{7}$ Santos et al. ${ }^{1}$ and Pereira et al. ${ }^{13}$ reported rates of $21 \%, 15.2 \%$ and $10 \%$, respectively. The $\mathrm{BH}$ study reported a mortality rate of $13.8 \%$. The average mortality among the four papers was $11.58 \%$.

\section{Epidemiology in the State of São Paulo}

The greatest number of studies (five) were performed in the southeastern state of São Paulo. ${ }^{1,6-9}$ Three of these studies were based on hospitals located in three different regions of the capital, São Paulo. ${ }^{1,7,8}$ Two other papers were conducted in the metropolitan area around São Paulo city. ${ }^{6,9}$ 


\section{Epidemiology of severe cervical SI}

One study was prospectively conducted over 10 years in northern São Paulo. ${ }^{1}$ This study selected for analysis only unstable or neurologically damaged patients with cervical spine lesions. All patients with severe cervical SI in northern São Paulo were included.

In this study, 217 hospitalized patients were evaluated. An average of 21.6 cases were seen annually, or 1.8 cases per month. The mean patient age was 36.75 years. The 20 to 40 -year-old age bracket had the highest rate of injury, corresponding to $52.6 \%$ of all patients. Patients were predominantly male: 191 male $(88.01 \%)$ $v s$. only 26 female patients (11.99\%). The ratio of men to women was 7.35:1. Injuries in the craniocervical region were reported in $43(19.8 \%)$ cases, whereas subaxial injuries in the cervical region were observed in $174(80.2 \%)$ cases. The latter were associated with more severe neurological lesions. In addition, $40.6 \%$ of patients presented with complications in other organ systems. Several patients presented with multiple complications, and 33 (15.02\%) patients died. Of the hospitalized patients, 4 patients presenting Grade A on the American Spinal Injury Association (ASIA) scale evolved to Grade C, 1 patient presenting at ASIA Grade A evolved to Grade B, and 2 patients evolved to Grade E. Two patients who had been admitted without neurological lesions evolved to ASIA Grade C (1 patient post-surgery and 1 patient post-traction). Two patients initially presenting at ASIA Grade E evolved to Grade D, and another developed the clinical symptoms of central cord syndrome. On average, patients with incomplete lesions improved one ASIA grade in classification during hospitalization.

\section{National studies}

In 2001, Masini ${ }^{2}$ conducted a one-year study based on the national public health information system (Datasus). Only SCI patients were studied, and data were collected from 92 patients. A total of $23 \%$ of the 872 hospitals responded to the questionnaire. In 1992, da Paz et al. ${ }^{3}$ conducted a study based on hospitalized patents interviewed by nurses, which revealed the prevalence of hospitalized SCI patients. ${ }^{14}$ The average patient age was $30.3 \pm 1.1$ (6-56), and $80.6 \%$ were male. In this group, $87 \%$ had complete cord lesions (ASIA A), with 61 paraplegic and 33 quadriplegic patients. Among the 138 patients, spinal injuries were most frequently caused by traffic accidents (41.7\%), gunshot wounds (26.9\%), falls from heights (14.8\%) and shallow diving (9.3\%). This was an inhospital SI prevalence study. Epidemiological data are summarized in table 4 .

\section{Discussion}

Brazil has almost 200 million inhabitants and is the fifth largest country in the world. Brazil contains 26 states spread over an area of $876.599 \mathrm{~km}^{2}$ and has regions of both high (southeast) and lower population density (north).

Epidemiological patterns are expected to differ between states according to the socioeconomic distribution. The age of the population has changed in recent years, with a smaller proportion of people younger than 25 years old and a greater proportion of people older than 65 years old (7.4\%). ${ }^{16}$ Spinal trauma is not a notifiable condition, which makes it difficult to collect concrete data regarding the incidence or prevalence in certain states. ${ }^{11}$ Epidemiological studies aiming to study SI find it difficult to represent reality due to the inability to determine whether the known cases correctly account for a large area. An ideal way to perform an epidemiological study is to use an enclosed area and have accurate counts of the population and events without interference from external factors. However, this theoretical system is difficult to reproduce. ${ }^{1}$

The first Brazilian hospital survey on the prevalence of SI was published in 1992. One conclusion of this study was that $8.6 \%$ of hospital beds were occupied by Brazilian patients with spinal cord injuries. ${ }^{2}$ In the present study, we calculated incidences and estimated SI causes by pooling data from all known Brazilian SI epidemiological studies. Data were not stratified by publication date. As missing data can easily alter real data, we can only provide gross estimates.

The two main causes of SI in Brazil were falls and car accidents. Fall from slab represented the most common cause of spinal trauma in most parts of the country.

The disorganized growth of populations in large urban areas, coupled with the lack of infrastructure for leisure and recreation, were associated with increased incidence of falls and SI. ${ }^{9}$

In the majority of countries, the incidence varies from 15 to 50 new cases per year. Prevalence rates vary between 11 and 112 cases per million persons per year. ${ }^{1}$ In this review, the incidence was estimated to fall between 16 and 26 cases per million inhabitants per year. The Brazilian incidence of SCI was therefore similar to the previously published incidences in other countries.

Trauma to the cervical spine is associated with the highest rates of mortality and morbidity among all types of spinal trauma. ${ }^{1}$ Among the surveyed studies, an average of $36,5 \%$ of SI cases occurred in the cervical spine. 


\begin{tabular}{|c|c|c|c|c|c|c|c|}
\hline \multicolumn{8}{|c|}{ Table 4 - Summary of all studies } \\
\hline Author & Place & Segment & Methods & Age & $\begin{array}{l}\text { Gender } \\
\text { \%male }\end{array}$ & Causes & $\begin{array}{l}\text { Neurologic impairment } \\
\text { (ASIA/Frankel scale) }\end{array}$ \\
\hline $\begin{array}{l}\text { Anderle et } \\
\text { al. }, 2010^{6}\end{array}$ & $\begin{array}{l}\text { Francisco } \\
\text { Morato }\end{array}$ & $\begin{array}{l}\text { C0C3: } 1.4 \% \text {; C3-C7: } \\
34.7 \% \text {; } 14.4 \% ; \\
\text { TL: } 40.5 \% ; \\
\text { L: } 8.6 \%\end{array}$ & $\begin{array}{l}\text { Hospital- } \\
\text { based }\end{array}$ & & 73 & $\begin{array}{c}\text { Fall from rooftop: } 36.4 \% \text {; } \\
\text { car accident: } 11.6 \% ; \\
\text { fall from height: } 8.7 \% \text {; } \\
\text { motorcycle: } 7.2 \%\end{array}$ & $\begin{array}{l}E=56.5 \% \\
A=26.1 \%\end{array}$ \\
\hline $\mathrm{BH}_{\text {project }}^{*}$ & Belo Horizonte & $\begin{array}{c}\text { C: } 57.1 \% \text {; cervico- } \\
\text { thoracic: } 5.8 \% \text {; } \\
\text { T: } 11.6 \% \text {; Tl: } 2.2 \% \text {; } \\
\text { L: } 7.1 \% \text {; unknown: } 16 \%\end{array}$ & $\begin{array}{l}\text { Prospective } \\
\text { study }\end{array}$ & 35 & 86.6 & $\begin{array}{c}\text { Auto }=39.8 \% ; \text { fall } \\
=34.8 \% ; \text { roll over }= \\
7.2 \% ; \text { shallow diving } \\
=2.9 \% ; \text { stab wound }= \\
0.8 \% ; \text { other }=5.8 \%\end{array}$ & $\begin{array}{c}A=23 \% ; B=2 \% ; C= \\
3 \% ; D=2 \% ; E=70 \%\end{array}$ \\
\hline $\begin{array}{l}\text { Barros e } \\
\text { Basso, } 2005^{10}\end{array}$ & Goiás & $\begin{array}{c}\mathrm{TL}=51 \% \\
\mathrm{C}=45 \% \\
\text { SCIWORA }=3 \%\end{array}$ & $\begin{array}{l}\text { Hospital- } \\
\text { based }\end{array}$ & 27 & 86.2 & $\begin{array}{c}\text { Auto: } 26 \% \text {; motorcycle: } \\
\text { 19\%; fall: } 31 \% \text {; } \\
\text { gunshot: } 13 \% \text {; diving: } \\
9 \% \text {; other: } 8 \%\end{array}$ & $\begin{array}{c}\text { e: } 44 \% \text {; tetraplegia: } \\
\text { 17\%; paraplegia: } \\
26 \% \text {; tetraparesis: } \\
4 \% \text {; paraparesis: } \\
2 \% \text {; other: } 7 \%\end{array}$ \\
\hline $\begin{array}{l}\text { Barros et } \\
\text { al., } 1990^{7}\end{array}$ & São Paulo & Only cervical spine lesions & $\begin{array}{l}\text { Hospital- } \\
\text { based }\end{array}$ & & 91.8 & $\begin{array}{l}\text { Gunshot: } 36.7 \% \text {; } \\
\text { traffic accident: } 26.9 \% \text {; } \\
\text { fall: } 22.4 \% \text {; diving: } \\
\text { 7.7\%; other: } 2.3 \%\end{array}$ & Only cord injuries \\
\hline $\begin{array}{l}\text { Campos et } \\
\text { al., } 2008^{8}\end{array}$ & $\begin{array}{l}\text { São Paulo } \\
\text { south }\end{array}$ & $\begin{array}{c}\mathrm{C}=36 \% \\
\mathrm{TL}=64 \%\end{array}$ & $\begin{array}{l}\text { Hospital- } \\
\text { based }\end{array}$ & & 86 & $\begin{array}{l}\text { Fall }=40 \% ; \text { auto }=25 \% \\
\text { gunshot }=7 \% ; \text { diving } \\
=3 \% ; \text { violence }=2 \%\end{array}$ & - \\
\hline $\begin{array}{l}\text { Gonçalves } \\
\text { et al., } 2007^{9}\end{array}$ & Santo André & $C=30>4$ & $\begin{array}{l}\text { Hospital- } \\
\text { based }\end{array}$ & & 83 & $\begin{array}{c}\text { Fall }=47 \% ; \text { motorcycle } \\
=14 \% ; \text { FAF }=18 \% ; \\
\text { auto }=10 \%\end{array}$ & - \\
\hline $\begin{array}{l}\text { Souza Junior } \\
\text { et al., } 2002^{11}\end{array}$ & Belém & $\begin{aligned} \mathrm{C} & =36.25 \\
\mathrm{~T} & =38.75 \\
\mathrm{~L} & =25 \%\end{aligned}$ & $\begin{array}{l}\text { Hospital- } \\
\text { based } \\
\text { prospective }\end{array}$ & & 83.75 & $\begin{array}{l}\text { Fall }=33 \text {; auto }=19 ; \\
\text { violence }=13 ; \text { diving } \\
\quad=4 \text { other }=10\end{array}$ & $\begin{array}{l}A=26 ; B=7 ; C= \\
13 ; D=11 ; E=23\end{array}$ \\
\hline $\begin{array}{l}\text { Leal Filho et } \\
\text { al., } 2008^{12}\end{array}$ & Teresina & $\begin{array}{l}\mathrm{C}=48.3 \% \\
\mathrm{~T}=25.8 \% \\
\mathrm{~L}=25.8 \%\end{array}$ & $\begin{array}{l}\text { Hospital- } \\
\text { based }\end{array}$ & & 86.3 & $\begin{array}{c}\text { Fall }=38.3 \% ; \text { auto }= \\
22 \% ; \text { gunshot }=11.9 \% ; \\
\text { motorcycle }=9.1 \% ; \text { diving } \\
=6.5 \% ; \text { local diving }= \\
6.2 \% ; \text { run over }=3.9 \% ; \\
\text { physical aggression }= \\
1.3 \% ; \text { knife }=0.8 \%\end{array}$ & $\begin{array}{c}\mathrm{A}=50 \% ; \mathrm{B}=3.4 \% \\
\mathrm{C}=16.3 \% ; \mathrm{D}= \\
14.8 \% ; \mathrm{E}=15.5 \%\end{array}$ \\
\hline Masini, $2001^{2}$ & Brasil & Only cord injuries & $\begin{array}{c}\text { Data sus and } \\
\text { questionary }\end{array}$ & 30.4 & 90 & $\begin{array}{l}\text { Transit accident: } 30 \% \text {; } \\
\text { fall: } 21 \% \text {; gunshot: } 20 \% \\
\text { sports }=2 \%\end{array}$ & Only cord injuries \\
\hline $\begin{array}{l}\text { Paz et al., } \\
1992^{3}\end{array}$ & Brazil & & $\begin{array}{c}\text { Transversal } \\
\text { study }\end{array}$ & 30.3 & 80.6 & $\begin{array}{c}\text { Traffic accident }=41.7 \% \\
\quad \text { firearm }=26.9 \% \\
\text { fall from height }=14.8 \% \\
\text { shallow diving }=9.3 \% \\
\text { knife wounds }=0.9 \% \\
\text { work accident }=21.3 \%\end{array}$ & $\begin{array}{c}\text { Only cord injuries } \\
\mathrm{A}=87 \% \text { (61 paraplegic } \\
\text { and } 33 \text { quadriplegic) }\end{array}$ \\
\hline $\begin{array}{l}\text { Pereira et } \\
\text { al., } 2009^{13}\end{array}$ & Recife & $\begin{array}{l}\text { L1: 38.9\%; T12: } \\
\text { 18.5\%; L2: 11.1\% }\end{array}$ & $\begin{array}{l}\text { Hospital- } \\
\text { based }\end{array}$ & 39 & 73.8 & $\begin{array}{c}\text { Fall from height }=61.9 \% \\
\text { motorcycle }=19.05 \% \\
\text { auto }=4.76 \% \text {; gunshot }= \\
4.76 \% ; \text { other }=9.52 \%\end{array}$ & $\begin{array}{c}\mathrm{A}=2.38 \% ; \mathrm{B}= \\
4.76 \% ; \mathrm{C}=2.38 \% ; \mathrm{D} \\
=4.76 \% ; \mathrm{E}=85.7 \%\end{array}$ \\
\hline $\begin{array}{l}\text { Pereira e } \\
\text { Jesus, } 2011^{14}\end{array}$ & Sergipe & $\begin{array}{l}\mathrm{C}=48.3 \\
\mathrm{~T}=25.8 \\
\mathrm{~L}=25.9\end{array}$ & $\begin{array}{l}\text { Hospital- } \\
\text { based }\end{array}$ & 34.5 & 88.3 & $\begin{array}{c}\text { Auto }=40.8 \% ; \\
\text { gunshot }=27.5 \% ; \\
\text { fall }=23.3 \% ; \text { stab } \\
\text { wound }=4.2 \% ; \text { shallow } \\
\text { diving }=3.3 \% \text {; physical } \\
\text { aggression }=0.8 \%\end{array}$ & \\
\hline $\begin{array}{l}\text { Santos et } \\
\text { al., } 2009^{1}\end{array}$ & $\begin{array}{l}\text { São Paulo } \\
\text { (north) }\end{array}$ & Only cervical spine & $\begin{array}{l}\text { Hospital- } \\
\text { based }\end{array}$ & 36.5 & 80.01 & & $\begin{array}{l}A=28 \% ; B=5 \% ; C= \\
6 \% ; D=10 \% ; E=43 \% \\
\quad \text { central cord }=6 \%\end{array}$ \\
\hline $\begin{array}{l}\text { Souza Junior } \\
\text { et al., } 2003^{15}\end{array}$ & Belém & $\begin{array}{l}C=32 \% ; T=35.6 \\
L=34.8 ; T L=7.6\end{array}$ & $\begin{array}{l}\text { Hospital- } \\
\text { based }\end{array}$ & & 89.2 & $\begin{array}{c}\text { Fall } 39.6 \% \text {; violence } \\
24.4 \text {; car accident } 8.4 \% \text {; } \\
\text { diving } 7.2 \% \text {; other } 3.2 \%\end{array}$ & $\begin{array}{c}A=41.6 \% ; B=6 \% \\
C=10.8 \% ; D= \\
14.8 \% ; E=26.8 \%\end{array}$ \\
\hline
\end{tabular}

* Personal communication. Segments: C0C3: occipitoatlantoaxial injuries; $\mathrm{C}=$ cervical spine; T: thoracic spine; TL: thoracolumbar spine; L: lumbar spine. 


\section{Conclusion}

In conclusion, although there are several limitations related to using data from different studies for epidemiological research, the reports from individual states/cities enable estimation of the true state of SI epidemiology in Brazil. Regional studies with periodic updates have great potential to reveal the epidemiology of this important morbidity.

\section{References}

1. Santos EA, Filho WJ, Possatti LL, Bittencourt LR, Fontoura EA, Botelho RV. Epidemiology of severe cervical spinal trauma in the north area of São Paulo City: a 10-year prospective study. Clinical article. J Neurosurg Spine. 2009;11(1):34-41.

2. Masini M. Estimativa da incidência e prevalência de lesão medular no Brasil. J Bras Neurocirurg. 2001;12(2):97-100.

3. Paz AC, Beraldo PS, Almeida MC, Neves EG, Alves CM, Khan P. Traumatic injury to the spinal cord. Prevalence in Brazilian hospitals. Paraplegia. 1992;30(9):636-40.

4. Silva CLC, Defino HLA. Estudo epidemiológico das fraturas da coluna cervical por mergulho na cidade de Ribeirão Preto-SP. Medicina Ribeirão Preto. 2002;35:41-7.

5. Araújo Júnior FA, Heinrich CB, Cunha MLV, Veríssimo DCA, Rehder R, Pinto ASP, et al. Traumatismo raquimedular por ferimento de projétil de arma de fogo: avaliação epidemiológica. Coluna/Columna. 2011;10(4):290-2.

6. Anderle DV, Joaquim AF, Soares MS, Miura FK, Silva FL, Veiga JCE, et al. Avaliação epidemiológica dos pacientes com traumatismo raquimedular operados no Hospital Estadual Professor Carlos da Silva Lacaz. Coluna/Columna. 2010;9(1):58-61.

7. Barros TEP, Taricco MA, Oliveira RP, Greve JMA, Santos LCR, Napoli MMM. Estudo epidemiológico dos pacientes com traumatismo da coluna vertebral e déficit neurológico, internados no Instituto de Ortopedia e Traumatologia do Hospital das Clínicas da Faculdade de Medicina da USP. Rev Hosp Clin Fac Med S Paulo. 1990;45(3):123-6.
8. Campos MF, Ribeiro AT, Listik S, Pereira CAB, Sobrinho JA, Rapaport A. Epidemiologia do traumatismo da coluna vertebral. Rev Col Bras Cir. 2008;35(2):88-93.

9. Gonçalves $A M T$, Rosa LN, D'Ângelo CT, Savordelli CL, Bonin GL, Squarcino IM, et al. Aspectos epidemiológicos da lesão medular traumática na área de referência do Hospital Estadual Mario Covas. Arq Med ABC. 2007;32(2):64-6.

10. Barros MN, Basso RC. Trauma raquimedular - perfil epidemiológico dos pacientes atendidos pelo serviço público do estado de Goiás nos anos de 2000 a 2003. Fisioter Bras. 2005;6(2):141-4.

11. Souza Júnior MF, Bastos BPR, Jallageas DN, Medeiros AAA Perfil epidemiológico de 80 pacientes com traumatismo raquimedular, internados no Hospital do Pronto-Socorro Municipal de Belém, PA, no período de janeiro a setembro de 2002. J Bras Neurocirurg. 2002;13(3):92-8.

12. Leal-Filho MB, Borges G, Almeida BR, Aguiar Ade A, Vieira MA, Dantas Kda S, et al. Spinal cord injury: epidemiological study of 386 cases with emphasis on those patients admitted more than four hours after the trauma. Arq Neuropsiquiatr. 2008;66(2B):365-8.

13. Pereira AFF, Portela LED, Lima GDA, Carneiro WCG, Ferreira MAC, Rangel TAM, et al. Avaliação epidemiológica das fraturas da coluna torácica e lombar dos pacientes atendidos no Serviço de Ortopedia e Traumatologia do Hospital Getúlio Vargas em Recife/PE. Coluna/Columna. 2009;8(4):395-400.

14. Pereira CU, Jesus RM. Epidemiology of spinal injury in Aracaju. A prospective series. J Bras Neurocirurg. 2011;22(2):26-31.

15. Souza Junior MF, Neves ACA, Medeiros AAA, Jallageas DN . Características epidemiológicas do trauma raquimedular na Amazônia: análise prospectiva de 250 casos. J Bras Neurocirurg. 2003;14(3):97-104.

16. IBGE - Instituto Brasileiro de Geografia e Estatística. Sinopse do senso demográfico 2010: evolução demográfica 1950-2010. Disponível em: <http://www.ibge.gov.br/home/ presidencia/noticias/imprensa/ppts/0000000403.pdf>. Acesso em: 5 abril 2014.

Correspondence address

Ricardo Vieira Botelho

Rua Tuim, 585 (122-A), Moema

04514-102 - São Paulo, SP, Brazil

Phone: (55 11) 98111-8157

E-mail: bitbot@uol.com.br 